GLOBAL JOURNAL OF ENGINEERING RESEARCH VOL 11, NO. 1, 2012: 47-52

COPYRIGHT@ BACHUDO SCIENCE CO. LTD PRINTED IN NIGERIA. ISSN 1596-292x

www.globaliournalseries.com; Info@globaljournalseries.com

\title{
SUITABILITY EVALUATION OF SURFACE WATER FOR IRRIGATION: A CASE STUDY OF RIVER MU IN MAKURDI, BENUE STATE, NIGERIA
}

THERESA U. NWAKONOBI AND T. GWAZA

(Received 31, October 2011; Revision Accepted 8, March 2012)

\begin{abstract}
River Mu in Makurdi Area of Benue State, Nigeria, was evaluated for its suitability as irrigation water source. Both qualitative and quantitative studies of the river water were carried out. Results of laboratory analysis show that the concentration values of physical and chemical parameters such as electrical conductivity, $\mathrm{pH}$, temperature, Total dissolved solid, Alkalinity, Magnesium, Chlorine, Boron, Silica, Fluoride, chemical oxygen demand, sodium, potassium, calcium, manganese, Nitrate-Nitrogen and free carbon dioxide fall within the acceptable limit except for Boron and potassium. The discharge of the river was determined as $22.93 \mathrm{~m}^{3} / \mathrm{s}$ using the float method giving an estimated average annual discharge (yield) of $723,120,480 \mathrm{~m}^{3}$. This supply volume exceeds the crop water requirement of sugar cane crop which is dominantly cultivated around River Mu for dry season irrigation.
\end{abstract}

KEYWORDS: Suitability; Irrigation; Surface water; River Mu; River Discharge

\section{INTRODUCTION}

Water for irrigation is obtained from surface and ground water sources. Surface sources include lakes, streams, river, reservoirs, and water-user association distribution facilities. The suitability of a water source for irrigation depends on several factors such as the quality of the water and the ability of the source to supply the total irrigation requirements year after year. According to Ayers and Westcot (1994) irrigated agriculture is dependent on an adequate water supply of usable quality. The information on concentration of some important chemical constituents of water is necessary to assess their suitability for irrigation (Hakim et al, 2009).

In irrigation water evaluation, emphases are placed on the chemical and physical characteristics of the water and only rarely are any other factors considered important (Ayers and Westcot, 1994). According to Tanninem et al (2005) as reported in Hakim et al (2009) specific water may be suitable for irrigation but may not be suitable for drinking and industrial uses due to presence of some other ions at toxic level. Thus, a highly saline water supply must not be applied more frequently and in large amount than good quality water (Wynn and Graylord, 1987). Problems of water quality are therefore encountered in planning for water supply and irrigation projects and in disposal of waste.

The river and stream discharge is measured using various techniques. The common method for measuring river flow is to multiply a measured sectional area by a measured flow velocity (Fukani et al, 2008). Portable current meters are normally used while rod floats have been typically used during floods (MLIT, 2002). Non-contact type meter which are of two types are also in use for measuring river flow viz: the Doppler-type current meter, which measures the surface velocities of river flow using radio waves or supersonic waves and the image processing type current meter, which measures the velocities of river surface pattern using video images. Fukani et al, (2008)

Theresa U. Nwakonobi, Department of Agricultural and Environmental Engineering, University of Agriculture, P.M.B. 2373 Makurdi, Benue State, Nigeria.

T. Gwaza, Department of Agricultural and Environmental Engineering, University of Agriculture, P.M.B. 2373 Makurdi, Benue State, Nigeria. 
confirmed the applicability of Doppler-type current meter and recommended it as a substitute to conventional method of river flow measurement. According to Musa (2001) most of the growth in crop production needed to meet population increases over the past five decades in Nigeria has come from irrigated agriculture. The study becomes necessary in order to provide adequate data that would be useful for the planning, design and execution of any irrigation project in the study area, Makurdi. In this study, the qualitative and quantitative analysis of River $\mathrm{Mu}$ in Makurdi local government Area of Benue State, Nigeria was carried out to determine the suitability of the river water for irrigation project. The specific objectives are to:

- Evaluate the levels of some pollutants in river $\mathrm{Mu}$;

- Carry out preliminary study on the determination of the volume flow rate of the river as well as total supply volume in a year; and

- Provide basic information for the successful planning, design and operation of irrigation project around the river area.

\section{METHODOLOGY}

\subsection{Location and Sampling Method}

River $\mathrm{Mu}$ is believed to be a representative of an area of square kilometers of the ferruginous tropical southern Guinea savanna zone of Benue State. It is within the longitudes $8^{0}$ $33^{\prime}-8^{0} 36^{\prime}$ East and latitudes $7^{0}$ North. The topography of the surrounding river basin on which the study is based is fairly representative of plains which can be described as undulating plain with very broad and gentle slopes lying at an altitude between 90 to 120 metres above mean sea level.

Water samples were collected at different times of the day, that is, morning, afternoon and evening. The water samples at each time were scooped at different points along the river reach using plastic container and then mixed together to obtain a true representative sample. The samples were taken to laboratory and subjected to various analyses to establish the degree of pollutant viz: Hydrogen ion concentration $(\mathrm{pH})$, turbidity, temperature, alkalinity, Magnesium, Chlorine, Boron, Silica, Fluoride, Chemical Oxygen demand (COD), Sodium, Potassium,
Calcium, Manganese, Nitrate, free Carbon dioxide and electrical conductivity.

\subsection{Testing Methods}

The $\mathrm{pH}$ was determined using standard method for examination of water (Clesceri et al, 1989). The turbidity of the river water was determined after APHA (1998). The temperature was measured with a probe instrument. Magnesium was determined by spectrometric analysis, while the Chemical Oxygen Demand (COD) was determined by calorimetric method (APHA, 1998). Manganese, Chloride and free Carbon dioxide (CO2) were determined by mercuric nitrate titrimetric method as described by APHA (1998). Silica was determined by the molybdate spectrophotometric method described by APHA (1998). Nitrate was determined by the spectrophotometric sodium salicylate method. Potassium and sodium were determined by standard AOAC (1984) methods, using the flame photometer. Calcium and magnesium ions were estimated from complexometric titration (APHA, 1998). Total alkalinity was determined by titration while Boron and Flourine were determined calorimetrically. Conductivity was determined with a conductivity meter as described by APHA (1998) and Total dissolved solid (TDS) determined with a TDS meter.

\subsection{Discharge Measurement}

The float method was used to determine the volume of water flowing per unit time in the river (Gierke, 2002; Fukani, 2008). The river flow measurements were carried out in the months of December, January, February, and March (i.e. dry season). A section of the river measuring $54 \mathrm{~m}$ in length and $22 \mathrm{~m}$ in width was chosen for the experiment. The depth of the river was measured at different periods of the year and the average depth determined. This was carried out with the aid of a gauge stick. During the field measurements a cork floating object was released from one end of selected section of the river and the time taken to reach the other end of the section was noted with the aid of a stop watch. Figure 1 shows the float-method set up for Mu river flow measurement. The experiment was carried out 3 times for each month bringing the total number of measurements to 12 for the four months chosen. The average time was taken for each month. Figure 2 shows the cross section of Mu river. 
End time, $\mathrm{t}$

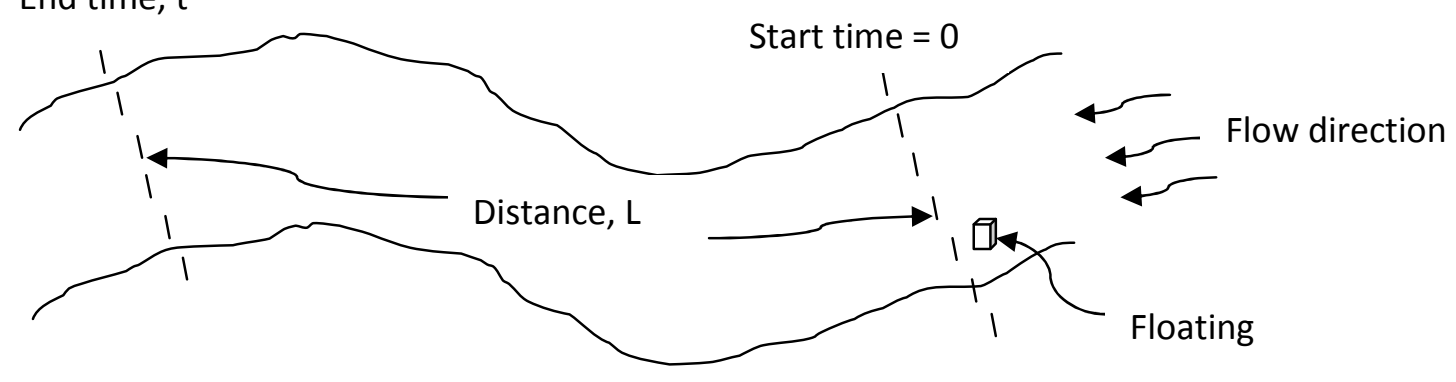

Figure 1: Float-method set up for measuring the river flow

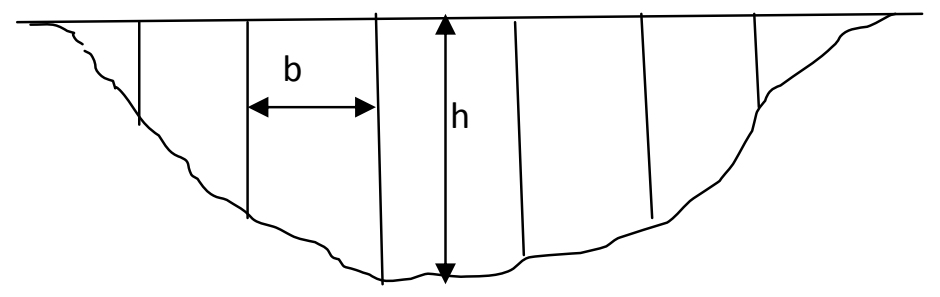

$$
\begin{aligned}
& b=\text { width of strip } \\
& h=\text { depth of strip }
\end{aligned}
$$

Figure 2: A typical cross-section of Mu river

\section{RESULTS AND DISCUSSION}

\subsection{Water Quality}

The average values of the physical and chemical parameters determined for the river $\mathrm{Mu}$ are as presented in Table1. The $\mathrm{pH}$ value of the river is 7.2 and is within the acceptable limit of 6 - 8.4 which is the range within which most biological activities occur (Ayers and Westcot, 1994). According to Hakim et al (2009) estimated water containing TDS less than $1000 \mathrm{mg} / \mathrm{l}$ can be considered to be 'fresh water' for irrigation use and will not affect the osmotic pressure of soil solution. The total dissolved solid (TDS) value obtained for river $\mathrm{Mu}$ water sample is $20.4 \mathrm{mg} / \mathrm{l}$ and is within the acceptable limit (Ayers and Westcot, 1994). The electrical conductivity value was obtained as $40.6 \mathrm{mmhos} / \mathrm{cm}$. The level of concentration of sodium was found to be $10.63 \mathrm{mg} / \mathrm{l}$. The impact of sodium concentration in irrigation water is best described by the ratio referred to as sodium absorption ratio (SAR). This was estimated using standard equation as outlined by Richards (1954) and is given as follows:

$$
\mathrm{SAR}=\frac{\mathrm{Na}^{+}}{\sqrt{\frac{\mathrm{Ca}^{++}+\mathrm{Mg}^{++}}{2}}}
$$

The SAR was obtained as 4.17. According to Wilcox (1955) the water sample is "good grade and 'excellent' class based on SAR values. The acceptable range of sodium is $0-920 \mathrm{mg} / \mathrm{l}$. Thus, the value obtained is below the maximum allowable limit. The concentration value of chlorine which is $7 \mathrm{mg} / \mathrm{l}$ also falls within the acceptable range $(0-525 \mathrm{mg} / \mathrm{l})$. It is however, observed that the concentration of Boron which is $2.54 \mathrm{mg} / \mathrm{l}$ is above the maximum acceptable level $(2 \mathrm{mg} / \mathrm{l})$ (Ayers and Westcot, 1994). The toxicity of river water is therefore due to high concentration of Boron. This may be as a result of anthropogenic discharges (such as refuse, sludge and other agricultural wastes) into the river (Greenwich, 2004). The level of concentration of silica is $0.15 \mathrm{mg} / \mathrm{l}$ and is within the acceptable limit of $0-0.2 \mathrm{mg} / \mathrm{l}$. The value obtained for Chemical Oxygen Demand is $165 \mathrm{mg} / \mathrm{l}$. This indicates that most of the organic matter present in water can be chemically oxidized to carbon dioxide and water. 
The concentration of potassium is obtained as $8.96 \mathrm{mg} / \mathrm{l}$. This value is above the acceptable maximum limit which is $2 \mathrm{mg} / \mathrm{l}$. This high concentration value of potassium may be due to discharge from diffuse sources such as agricultural runoff including cattle waste, fertilizers, and pesticides which inundates local rivers. The values obtained for calcium and manganese are $4.7 \mathrm{mg} / \mathrm{l}$ and $0.12 \mathrm{mg} / \mathrm{l}$, respectively. The two respective values are below the acceptable maximum limit which is 800 $\mathrm{mg} / \mathrm{l}$ for calcium and $0.2 \mathrm{mg} / \mathrm{l}$ for manganese, respectively. The concentration of NitrateNitrogen is at the level of $0.09 \mathrm{mg} / \mathrm{l}$ and is within the acceptable range of $0-10 \mathrm{mg} / \mathrm{l}$ provided in the water quality guidelines (Ayers and Westcot, 1994). The electrical conductivity level was obtained as $40.6 \mathrm{mmhos} / \mathrm{cm}$ and this is within the acceptable range of $0-250 \mathrm{mmhos} / \mathrm{cm}$. This range indicates low salinity which is suitable for irrigation of most crops. The physical and chemical characteristics of River $\mathrm{Mu}$ are as presented in Table 1.

Table 1: Physical and Chemical Characteristics of River Mu

\begin{tabular}{|l|c|l|c|}
\hline Water Parameter & $\begin{array}{l}\text { Mean Concentration } \\
\text { level, mg/l }\end{array}$ & Water Parameter & $\begin{array}{l}\text { Mean Concentration } \\
\text { level, mg/l }\end{array}$ \\
\hline pH & 7.2 & $\begin{array}{l}\text { Chemical Oxygen } \\
\text { Demand (COD) }\end{array}$ & 165 \\
Temperature ( $\left.{ }^{\circ} \mathrm{C}\right)$ & 27.5 & Sodium & 10.6 \\
Total Dissolved Solid & 20.4 & Potassium & 8.96 \\
Alkalinity & 14 & Calcium & 5.6 \\
Magnesium & 8.4 & Manganese & 0.12 \\
Chlorine & 7 & Nitrate-Nitrogen & 0.09 \\
Boron & 2.54 & Free Carbon dioxide & 20.6 \\
Silica & 0.15 & Electrical Conductivity & 40.6 \\
Fluorine & 0.22 & (mmhos cm ${ }^{-1}$ ) & \\
& &
\end{tabular}

\section{Water Quantity}

The river discharge for each month was calculated using the expression as given by Gierke (2002):

$\mathrm{Q}=\mathrm{AV}$

Where: $\mathrm{Q}=$ Discharge of the river, $\mathrm{m}^{3} / \mathrm{s}$

$A=$ Cross-sectional area perpendicular to flow, $\mathrm{m}^{2}$

$\mathrm{V}=$ Average velocity of flow, $\mathrm{m} / \mathrm{s}$

The cross-sectional area of the river was obtained by dividing the width of the river into strips of equal size. The depth at the centre of each strip was taken (see Figure 2 above). The cross-sectional area of each strip was then estimated to get the average cross sectional area of the river. While the velocity was calculated as the distance covered by the average time taken in the float method as described above. The surface velocity value obtained was multiplied by the velocity correcting factor, 0.85 after (Gierke, 2002 ) in order to obtain the average velocity.
The estimated discharge of the Mu river in the various months of dry season are presented in Table 2. The value of River flow discharge obtained in the month of December, January, February and March are 19.48, 17.40, 34.85 and $19.99 \mathrm{~m}^{3} / \mathrm{s}$, respectively. This preliminary investigation indicates that River $\mathrm{Mu}$ has an average discharge value of $22.93 \mathrm{~m}^{3} / \mathrm{s}$ in dry season. The implication of this determination is that the minimum annual supply volume of the river is about $723,120,480 \mathrm{~m}^{3}$. The results of this study when compared with the water requirement of sugar cane crop as determined by Gwaza (2003) shows that River $\mathrm{Mu}$ is a suitable water source for irrigation of this crop. The supply volume of this river exceeds water requirement of sugar cane crop by 45.8 percent indicating its adequacy in supplying water for dry season irrigation in the surrounding area. However, the losses to other water uses need to be estimated before a recommendation can be made on $\mathrm{Mu}$ river as an adequate water source for irrigation in the area. 
Table 2: Mu river discharge for various month of dry season.

\begin{tabular}{lll}
\hline Month & Average river depth, $\mathrm{m}$ & Discharge, $\mathrm{m}^{3} / \mathrm{s}$ \\
\hline December & 9.0 & 19.48 \\
January & 5.5 & 17.40 \\
February & 11 & 34.85 \\
March & 10.1 & 19.19 \\
\hline Mean discharge & & 22.93 \\
\hline
\end{tabular}

\section{CONCLUSIONS}

River Mu in Makurdi area of Benue State is found to be a good source of water for irrigation in terms of both quality and quantity. Most of the chemical parameters have their concentration level within the acceptable range. Only Boron and Potassium were outside the acceptable range. Reduction and prevention of these two pollutants which may be from non-point sources water discharge could be achieved through public awareness, education, and training programs on non-point source pollution and best management practices. Set back and buffer zone requirements from watersheds may also be enforced by the regulatory agency. This is likely going to bring the concentration value of Boron and Potassium to acceptable range. Direct discharge of refuse and other agricultural waste into the river should be avoided to reduce Boron Concentration to non toxic level. However, other toxic parameters not assessed in this study still need to be investigated in order to strongly recommend River $\mathrm{Mu}$ as good irrigation water source.

The volume discharge of the river exceeds the water requirement of sugar cane crop and is capable of irrigating 10 hectares of land of sugar cane crop. Sugar cane has a high crop water requirement implying that the source is capable of irrigating more hectares of land planted with crops having less crop water requirement. However, the losses to other water uses need to be estimated before Mu river should be recommended as an adequate water source for irrigation in the area. Echo sounder method as well as use of current meter for velocity measurements should be employed in the future investigation of River Mu for irrigation suitability.

\section{REFERENCES}

APHA., 1998. Standard Methods for the Examination of Water and Waste Water.
American Public Health Association, Washington, D.C.

AOAC., 1984. Official Methods of Analysis, $14^{\text {th }}$ ed. Association of Official Analytical Chemists, Washington, D.C.

Ayers, R. S and Westcot, D. W., 1994. Water Quality Evaluation. Faocorporate Document Repository: Water Quality For Agriculture: Produced By: Agriculture And Consumer Protection.

Clesceri, L. S., Greenberg, A. E and Trussell, R. R., 1989. Standard Methods for the Examination of Water and Waste Water. 17th Ed., American Public Health Association, Washington DC., USA., pp: 1-175.

Fukami, K., Amou, J and Yoshitani, J., 2003. New Technological challenges on river flow observation and its technical Standard. Civil Engineering Journal, 45, (2): 22-29.

Fukami, K., Yamaguchi, $\mathrm{T}$ and Imamura, $\mathrm{H}$., 2008. Current Status of river discharge observation using non-contact current meter for operational use in Japan. World Environmental and Water Resources Congress , Ahupua'a, C: ASCE.

Gierke, J. S., 2002. ENG5300: Engineering Application in the Earth Sciences: River Velocity. Online Citation; http://www.cee. mtu.edu/sustainable_engineering/resourc es/publication.

GREEN FACTS., 2004. Fact on Health and Environment; Scientific Facts on: Source Document; Summary and Detail; http//www.greenfacts.org/glossary.

Gwaza, T., 2003. Evaluation of Quality and 
Quantity of Surface Water for Irrigation.

B.Eng. Project submitted to the Department of Agricultural Engineering. University of Agriculture, Makurdi, Benue State, Nigeria,

Hakim, M. A., Juraimi, A. S., Begum, M., Hasanuzzaman, M., Uddin, M. K and Islam, M. M., 2009. Suitability Evaluation of Groundwater for Irrigation, Drinking and Industrial purposes. American Journal of Environmental Sciences 5, (3): 413-419.

MLIT., 2002. Ministry of Land, Infrastructure and Transport. The Independent administrative Coorperation Public Work Research Institute under the editorial Supervision of the River Bureau of MLIT. 'Hydrological observation' Japan.

Musa, I. K., 2001, Challenges and opportunities for sustainable irrigation development in Nigeria. Lead paper, NIAE International Conference Proceedings, Enugu, 23; 1322.

Richards, L. A., 1954. Diagnosis and Improvement of Saline Alkali Soils. Agricultural Handbook 60, USDA and IBH Publishing Co. Ltd., New Delhi, India, 98-99.

Tanninen, J., Kamppinen, L and Nystrom, M., 2005. Pre-treatment and hybrid processes. Nanofiltration-Principles and Application. Advanced Technology Publisher, London, and ISBN: (13): 978-1-85617405-3.

Wilcox, L. V., 1955. Classification and uses of irrigation waters. USDA circular No. 969, 8PP.

Wynn, R. W and Graylord, V., 1987. Surface Irrigation theory and practice. Englewood cliffs, New Jessy; Prentice- Hall, Inc. PP.386. 